\title{
Satavar and safed musli-ingredients for herbal food: an appraisal
}

\begin{abstract}
Today, medicinal plants are finding diverse uses in the society from medicine to cosmetics, herbal drinks, herbal foods and other articles in daily uses. These play a significant role especially in modern time. Medicinal plants have been in major demand due to the great efficiency of herbal remedies and prized for their medicinal, flavoring and aromatic values. The movement is based on the belief that the plants have a vast potential for their curative medicinal uses as herbal food products. In this paper an attempt has made to understand the various aspects of two selected medicinal plants i.e. Stavar and Safed musli those are using as medicine. These may also use as ingredients for preparation of herbal food products.
\end{abstract}

Keywords: medicinal plant, safed musli, satavar, medicinal values, herbal food products, antimicrobial, antioxidant
Volume 8 Issue 3 - 2018

\author{
RK Goyal,' PK Singh,' SK Goyal' \\ 'Department of A. H. \& Dairying, India \\ ${ }^{2}$ Krishi Vigyan Kendra, Banaras Hindu University, India
}

Correspondence: RK Goyal, Department of A. H. \& Dairying, RBS College Bichpuri, Agra, India, Email drrajdairy@gmail.com

Received: November 25, 2017 | Published: May 29, 2018

\section{Introduction}

Medicinal plants are rich in secondary metabolites and are potential sources of drugs. These secondary metabolites include alkaloids, glycosides, coumarins, flavonoids, steroids, etc. Generally the whole plant, roots, stem, bark, leaves, flowers, fruits, gums and oleoresins, etc. are used. ${ }^{1}$ A large number of people in developing countries have traditionally depended on products derived from plants, especially from forests, for curing human and livestock ailments. Additionally, several aromatic plants are popular for domestic and commercial uses. Collectively they are called medicinal and aromatic plants (MAPs). About $12.5 \%$ of the $4,22,000$ plant species documented worldwide are reported to have medicinal values. With dwindling supplies from natural sources and increasing global demand, the medicinal and aromatic plants will need to be cultivated to ensure their regular supply for processing and value added products. ${ }^{2}$ Recently, the development of food products by supplements with herbal ingredients is important from nutritional and theraptic point of view. Now a day demand of herbal food products is increasing day by day. The production of such type of food product is more economical and profitable in the interest of health. ${ }^{3}$

Plants constitute an important source of natural products which differ widely in their structures, biological properties and mechanism of action. Various phytochemical components especially polyphenols, flavonoids, phenolic acids etc. are responsible for the free radical scavenging and antioxidant activity of the plants. Polyphenols possess many biological affects, mainly attributed to their antioxidant activities in scavenging free radicals, inhibition of peroxidation and chelation of transition metals. ${ }^{4}$ Over the world range of botanical species and plant parts from which they are derived, they can contribute significant variety and health benefits to the human diet. ${ }^{5}$

In view of deleterious side effects of synthetic anti-oxidant supplements on human health, the present day's focus is on antioxidants from natural sources. ${ }^{6}$ In spite of the advent of modern high throughput drug discovery and screening techniques, traditional knowledge systems have given clues to the discovery of valuable drugs. ${ }^{7}$ Traditional medicinal plants are often cheaper, locally available and easily consumable, raw or as simple medicinal preparations. Considerable research on pharmacognosy, chemistry, pharmacology and clinical therapeutics has been carried out on Ayurvedic medicinal plants in order to establish the scientific basis of their therapeutic potentials. ${ }^{8}$ Medicinal plants have only recently captured the attention of the scientific community as store house for bioactive compounds providing potential health benefits. As a result, there needs to be significant investment in human clinical trials to substantiate many of the hypothesized health benefits.

Recently, the development of food products by supplementing with herbal ingredients is important from nutritional and therapeutic point of view. The main sources of herbal ingredients are the edible medicinal plants, which are available in rural areas. Some edible medicinal plants like Stevia, Safed musli, Mulhathi, Brhami, Lemongrass, Tulsi, Ginger, Meethineem, Mint, Cardamom, turmeric, Oregano, thyme, marjoram, sage, basil, fenugreek, fennel, coriander, pimento, etc. can be used to develop food products. Various dairy products such as salted spiced buttermilk, whey based herbal beverages, flavored milk, ginger based ice-cream, herbal candies, herbal tea, medicinal ghee, panchamrit, etc are available in Indian market. These products help in curing of physiological disorders, certain diseases and other inborn defects of metabolism in children, young ones and old persons. Herbs and spices are used widely in the food industry as flavours and fragrances. However, they also exhibit useful antimicrobial and antioxidant properties. Many plant derived antimicrobial compounds have a wide spectrum of activity against bacteria, fungi and mycobacteria and this has led to suggestions that they could be used as natural preservatives in foods. Although, more than 1300 plants have been reported as potential sources of antimicrobial agents.

India is bestowed with a wealth of medicinal plants which are among the biggest repositories of herbal wealth in world. About 2000 indigenous plant species have curative properties. The Indian systems of the medicine have identified 1500 medicinal plants of which about 500 species are commonly used in the preparation of herbal drugs..$^{9,10}$ 
The revival of interest in natural drugs, especially those derived from plants, started in the last few decades mainly because of the widespread belief that "Green medicines" are healthier and safer than the synthetic ones. Medicinal plants are staging a comeback and an 'herbal renaissance' is blooming across the world. The WHO took note of the role that traditional medicine which can play in the extension of health services particularly in the remote rural areas. ${ }^{2}$ Today, more than 70 species of medicinal and aromatic plants are commercially cultivated in India. India's share is about 1.0 per cent in the World Trade Market with over 70 billion dollars. ${ }^{2}$ According to an estimate, medicinal and aromatic plants occupy an area of about $2,50,000$ hectares, producing raw material of worth Rs. 500 crore. ${ }^{11}$

India, with 2.4 per cent of world area and 8.0 per cent of global diversity is one of the 12 mega diversity hot spots. It is believed that one fifth of all plants found in India is medicinally important whereas, the world average stands at about 12.5 per cent. ${ }^{12}$ In India, medicinal and aromatic plants are cultivated on an area of merely about 0.4 million hectares. Some areas are famous for the cultivation of medicinal and aromatic plants; otherwise most of the produce is collected from forest. Now-a-days, some important medicinal and aromatic plants are grown by marginal and small farmers. ${ }^{13}$ Two herbal plants i.e. Satavar (Asparagus recemosus) and Safed musli (Chlorophytum borivilianum) having medicinal importance was taken in to account to unearth their worthiness as dairy supplement product. So it becomes imperative to have a glimpse of medicinal profiles of these herbal plants. It is in this context the following paragraphs are devoted to elaborate the medicinal profiles of these two herbal plants as here under.

\section{Satavari (Asparagus racemosus F. Liliaceae)}

Asparagus is one of the important genera of family Lilicaceae represents around 1500 species worldwide and are distributed in temperate and subtropical regions. It represents highly valuable plant species having therapeutically and nutraceutical importance, known as Satavari. Ayurveda considers it as a powerful rasayan drug capable of improving memory power, intelligence, physical strength and maintaining youthfulness. Plant has also ornamental value both for indoor and outdoor decorations. It is found throughout India, in all districts up to 1500 meters elevation.

Asparagus roots contain protein (22\%), fat (6.2\%), carbohydrate $(3.2 \%)$, vitamin B $(0.36 \%)$, vitamin C $(0.04 \%)$ and traces of vitamin A. It contains several alkaloids. Asparagamine A, a novel polycyclic alkaloid possessing antitumor activity is present in it. It contains four antioxytoxic saponins shatvarin I to IV. Analysis of root tubers at optimum harvesting stage of two years, recorded total free amino acids $(0.429 \%)$, soluble sugar $(45.07 \%)$, insoluble sugar $(4.79 \%)$ and total saponins $(1.77 \%){ }^{14}$

Tuber roots are demulcent, diuretic, aphrodisiac, tonic, alterative antiseptic, antidysentric, galactogogue and antispasmodic. Its roots are used in leucorrhoea, seminal debility, general debility, agalactia, headache, hysteria, reduces blood pressure, acidity and ulcer patient, etc. ${ }^{15}$ In Ayurveda, it is prescribed as a cooling agent and uterine tonic. Besides quenching thirst, its roots juice helps in cooling down the body from summer heat, curing hyper-activity and peptic ulcer. It contains good amount of mucilage that smoothes inner cavity of stomach. It relieves burning sensation while passing urine and is used in urinary tract infections. It contains anticancer agent asparagine that is useful against leukemia. It also contains active antioxytoxic saponins that have good antispasmodic effect and specific action on uterine musculature. It is a very good relaxant to uterine muscles, especially during pregnancy and is used to prevent abortion and pre-term labour on place of progesterone preparations. Its powder boiled with milk is generally used to prevent abortion. It is a good remedy for vaginal discharges like leucorrhoea, uterine disorders, and excess of bleeding and colic pain. Its preparations with milk help to increase breast milk in lactating women. Its proper use helps in avoiding excess blood loss during periods. It clears out infections and abnormalities of uterine cavity hence; it is used to rectify infertility in women. The roots have an important ingredient for preparations like Satavarigulam, Shatavarighrtam, Sahacaradikulambu, rasnadi kasayam, Dhatryadi ghrtam etc.

Kirtikar \& $\mathrm{Basu}^{16}$ stated that asparagus racemosus wild represents highly valuable plant species having therapeutically and nutraceutical importance in addition to being consumed as vegetable. Known as Satavari, Ayurveda considers it as a powerful rasayana drug capable of improving memory power, intelligence, physical strength and maintaining youthfulness. Plant has also ornamental value both for indoor and outdoor decorations. It is found throughout India, in all districts up to $1500 \mathrm{M}$ elevation. It is also distributed in Africa, through South Asia to China, South Malaysia and Northern Australia (Table 1). ${ }^{17}$

Table I Variability in germplasm accession of asparagus

\begin{tabular}{lll}
\hline S. No & Characteristics & Range \\
\hline 1 & Plant height $(\mathrm{cm})$ & $23.0-382.0$ \\
2 & No. of branches & $1.0-15.0$ \\
3 & No of roots & $28.0-355.0$ \\
4 & Length of the longest $\operatorname{root}(\mathrm{cm})$ & $32.0-82.5$ \\
5 & Girth of the longest $\operatorname{root}(\mathrm{cm})$ & $2.75-5.50$ \\
6 & Length of the shortest $\operatorname{root}(\mathrm{cm})$ & $6.0-19.5$ \\
7 & Girth of the shortest $\operatorname{root}(\mathrm{cm})$ & $1.2-3.5$ \\
8 & Root weight(g/ plant) & $200.0-2650.0$ \\
\hline
\end{tabular}

\section{Chemical composition}

According to Kirtikar \& Basu ${ }^{18}$ Asparagus roots contain protein $(22 \%)$, fat $(6.2 \%)$, Carbohydrates $(3.2 \%)$, Vitamin B $(0.36 \%)$, Vitamin C $(0.04 \%)$ and traces of vitamin A. It contains several alkaloids. Alcoholic extract yields asparagin, an anticancer agent. Asparagamine A, a novel polycyclic alkaloid passing antitumour activity is also present. ${ }^{19-21}$ It contains four antioxytoxic saponins shatavarin I to IV. Shatavarin IV is a glycoside of sarsapogenin having two molecules of rhamnose and one molecule of glucose. Leaves contain rutin, diosgenin and a flavonoid glycosides identified as quercetin-3-glucuronide. ${ }^{22,23}$ Flowers contain quercetin hypereside and rutin. Fruits contain glycosides of quercetin, rutin and hyperoside while fully ripe fruits contain cyanidin-3-galactoside and cyaniding3 -glucorhamnoside. ${ }^{24} \mathrm{Jain}^{25}$ reported that the analysis of root tubers at optimum harvesting stage of 2 year, recorded total free aminoacids $(0.429 \%)$, Soluble sugar $(45.0 \%)$, insoluble sugar $(4.79 \%)$ and total saponins $(1.77 \%)$. Sarasaponin, a steroid drug often used for mitotic chromosome preparation of plant cell is derived from Asparagus species. ${ }^{26}$

\section{Medicinal uses}

Shrivastava \& Pahapalkar $^{27}$ stated that the tuber is demulscent, diuretic, aphrodisiac, tonic, altrative, anticeptic, antidysentric, galactogogue and antispasmodic. In Ayurveda, it is prescribed as 
a cooling agent and uterinetonic. Besides quenching thirst, its root juice help in cooling down the body from summer heat, curing hyperacidity and peptic ulcer. ${ }^{14,28}$

The roots of satavar contains good amount of mucilage that soothes inner cavity of stomach. It relieves burning sensation while passing urine and is used in urinary tract infections. ${ }^{29,30}$ It contains anticancer agent asparagines that are useful against leukemia. ${ }^{31,32}$ Roots also contains active anti oxytoxic saponins that have good antispasmodic effect and specific action on uterine musculature.$^{33}$ It is very good relaxant to uterine muscles, especially during pregnancy and is used to prevent abortion and pre-term labour on place of progesterone preparations. Its powder boiled with milk is generally used to prevent abortion. ${ }^{34}$ It is a good remedy for vaginal discharges like leucorrhoea, uterine disorders and excess of bleeding and colic pain. ${ }^{35}$ Its preparation in milk helps in increasing breast milk in lactating women. ${ }^{36}$ Its proper use helps in avoiding excessive blood loss during periods. It clears out infections and abnormalities of uterine cavity and hence it is used to rectify infertility in women. ${ }^{9}$ The blanched young shoots are eaten raw, made into a preserve and candied. The roots form an important ingredient of preparations like Satavrigulam, Satavarighrtam, Sahacaradi Kulambu, Rasnadi Kasayam, Dhatryadighritam, etc. ${ }^{15}$

Results of research studies showed that Shatarin IV in doses of $20 \mu \mathrm{g}$ to $500 \mu \mathrm{g} \mathrm{ml}^{-1}$ blocked induced and spontaneous mobility of rabbit uterus. Aqueous extract of roots has inhibitory activity on hatching of eggs of Meloidogyne arenaria and Meloidogyne javanica. Fresh roots are used to feed the cattle for increase the milk yield. ${ }^{37}$

\section{Safed musli (Chlorophytum borivilianum)}

Safed musli or Chlorophytum borivilianum (Chloros means green and phyton means plant) is commonly known as Dholi musli and locally pronounced by the tribals of Rajasthan, Madhya Pradesh and Gujrat as Koli, Jhirna (Gharwal), Sepheta musli (Bombay) and Khairuwa (North-West Province). ${ }^{38}$ Safed musli is being grown naturally in Himalayan tarai, Uttarakhand, Western Uttar Pradesh, Chattisgarh, Southern part of Rajasthan, Western Madhya Pradesh and North Gujrat. It is distributed in the eastern part of Himalaya, Assam and Bihar. Generally, it grows in certain specified pockets on sloppy hill and widely distributed in tropical and subtropical regions. Commercial cultivation of safed musli has not caught up in our country. The plant grows wild in its natural habitat hence no statistics regarding area and production is available. ${ }^{11}$

The roots of safed musli are white, smooth and 3-5 inches long. A single plant produces 5-7 tuber roots. The roots of safed musli are used in therapeutic preparations against leucorrhoea. It has found common uses due to its aphrodisiac properties and as a tonic for lactating mothers and for women after delivery. Root is also used in commercial preparation of steroidal hormones. Generally, it is used for increasing vitality. Besides this, it is also used in many Ayurvedic preparations prescribed for joint pain, diarrhea and diabetes and also used as a blood purifier. The tubers of safed musli are also used as a substitute for European salad. ${ }^{39}$

A large number of people live in the surrounding of the forest for their subsistence. From the ancient times, the rural population used roots, shoots, stems, barks, leaves, flowers, etc. for preparation of traditional medicinal formulations to cure several human ailments. With the advancement of medicinal science and development of newer branches of therapy, people diverted herbal to laboratory based synthetic chemical drugs for quick relief. However, about $80 \%$ people of the developed countries are intending towards the plant based medicine system due to higher cost and side effect of the chemical drugs. The traditional knowledge gained over the period of time passed to the next generations through practices. Due to the nature of plant biodiversity of any region, such knowledge is very much specific to a particular locality.

The name Chlorophytum is derived from Greek word, Chloros meaning green and phyton pant. ${ }^{40}$ It belongs to family Liliaceae. Kirtikar $\& \mathrm{Basu}^{16}$ had classified it as a medicinal plant. A few Chlorophytum species, viz., C. arundinaceum Baker, ${ }^{41-43}$ C. attenuatum Baker ${ }^{43} C$. borivilianum Santapau and Fernades ${ }^{44} C$. breviscapum Dalaz ${ }^{45} C$. laxum $\mathrm{R} . \mathrm{Br}^{41}$ and C. tuberosum Baker ${ }^{42}$ are all grouped under one trade name of Safed musli which is used extensively in Ayurvedic medicines.

The genus Chlorophytum represents about 175 taxa of rhizomatous herbs distributed in the tropical parts of the world. The probable centre of origin is suggested as the tropical and subtropical Africa where 85 per cent of the species are found. Some of the species are cultivated for ornamental flowers. Thirteen species are reported to occur in India. At least 6-7 Chlorophytum species are supposed to be collected and treated as safed musli. The species Chlorophytum borivilianum came into prominence during 1980's. Each of the medicinal Chlorophytum species reported from India has a specific area of occurrence. ${ }^{46}$

Safed musli (Chlorophytum borivilianum) is commonly known as Dholi musli and locally pronounced by the tribals of Rajasthan, Madhya Pradesh and Gujrat as Koli, Jhirna (Gharwal), Sepheta musli (Bombay) and Khairuwa (North-west province). The genus Chlorophytum (Anthericaceae) with about 215 species is widely distributed in the tropical and subtropical regions. Herbs with short root stock emitting many fascicled roots, often thick, fleshy and tuber like. Leaves are radical, clustered, often broad rarely linear or laureate. White flower is of little horticultural value. ${ }^{38}$ The economic part of herb is roots. ${ }^{47}$

It is a small perennial herb with radial leaves. The roots tubers are fascicled, sessile, cylindrical, 1-8 in number, brown to black and white after peeling. The tubers are $3-10 \mathrm{~cm}$ long at maturity. Leaves are radical, 6-3 in number, spirally imbricate at the base, sessile with acute apex. The leaves are spreading horizontally; margins are waxy with parallel venation. It has a solitary scape, $15-30 \mathrm{~cm}$ long, terminal and unbranched. ${ }^{46}$

Safed musli is being grown naturally in foot hills of Himalayan, Uttaranchal, Chattisgarh, Southern part of Rajasthan, Western Madhya Pradesh, Western Uttar Pradesh and North Gujarat. It is distributed in the Eastern part of Himalaya, Assam and Bihar. ${ }^{48}$ Generally it grows in certain specified pockets on sloppy hills and widely distributed in tropical and subtropical regions. At present it is available only in those areas which are not accessible to cattle. ${ }^{11}$

In recent years, many farmers are getting attracted and showing interest in its cultivation on a large scale due to very high profitability. According to an estimate safed musli is cultivated on an area of 20 ha and its cultivation is spreading fast in other areas such as Kota, Jaipur and Jhalawar district of Rajasthan. ${ }^{47}$ Kurian \& Sankar ${ }^{49}$ reported that the safed musli Chlorophytum borivilianum is an Ayurvedic and Unani medicinal plant since ancient times. The plant is annual herb with suberect lanceolate leaves and tuberous roots systems. It is grown for vital natural oil present in the roots, which is used in preparation of health and sexual tonics. ${ }^{50}$ 
The crop of safed musli takes $80-90$ days to reach maturity. At maturity, leaves loose green colour, turn yellow and dry plants can be harvested at this stage if the planting material is not required for planting next season. Otherwise, harvesting is done in March-April. Each plant is dug carefully and tubers are washed with clean water. From October-November harvested crop all fleshy tubers are removed from the disc and peeled off and dried in shade. From March-April harvested crop, depending upon planting material requirement, 50-70 per cent of lengthy and thick tubers are removed from the disc and the remaining small and thin tubers (fingers) along with disc are stored for planting in next cropping season. Yield of fleshy roots varies from 5 to 8 tonnes per hectares, which on drying gives 0.6 to 1.2 tonnes. Dried root tubers are stored safely in airtight polypropylene bags with minimum loss of saponin content up to one year. ${ }^{49}$

\section{Proximate composition of safed musli}

According to Seth \& Bordia et al., ${ }^{38,50,51}$ the major constituents of safed musli are carbohydrates $(42 \%)$, proteins $(8-9 \%)$, root fibers (3-4\%), saponins $(2-17 \%)$. Chemically, safed musli constitutes carbohydrates, proteins, fiber and medicinal elements like steroids, saponins, sapogenins and minerals. ${ }^{50}$ Mishra $^{39}$ found 4.0 per cent saponin in dry roots of Chlorophytum borivilianum. The sapogenin (i.e. only hecogenin) was 0.18 per cent, while the sugar moiety constituted 3.80 per cent. The galactose $(0.73 \%)$, glucose $(0.76 \%)$, xylose $(0.74 \%)$, arabinose $(0.79 \%)$ and rhamnose $(0.78 \%)$ were found to be present in saponin hydrolyzate. He also analyzed the safed musli (Chlorophytum borivilianum) and elucidated its chemical profiles as delineated hereunder. (Table 2)

Table 2 Proximate composition of safed musli

\begin{tabular}{lll}
\hline S. No & Constituents & Value (\%) \\
\hline 1 & Saponin & 4.4 \\
2 & Total sugar & 39.1 \\
3 & Reducing sugar & 22.2 \\
4 & Non-reducing sugar & 16.9 \\
5 & Total protein & 8.5 \\
6 & Water soluble protein & 5.8 \\
7 & Crude fiber & 5 \\
\hline
\end{tabular}

\section{Medicinal Values}

Kirtikar \& Basu ${ }^{16}$ stated that the dried roots of safed musli are used in therapeutic preparations against leucorrhoea. It has common use due to aphrodisiac properties and as a tonic, in general for lactating mothers and for women after delivery. The possibility of using dietary saponin for reducing liver and serum cholesterol levels has been studied by Newman et al..$^{52}$ The wide ranges of usages of saponins are in soft drinks, beers, confectionary, shampoos, soaps, etc. It have also been used for other pharmaceuticals ${ }^{53}$ like preparations of antihemorrhoidal ointments. ${ }^{54}$

Sambasiva et al., ${ }^{55}$ reported that Chlorophytum arundinaceum facilitates sex behaviour in males besides other indigenous plants such as Mucuna prurita and Eulophia campestris. Tarafder ${ }^{56}$ studied the plants which are used for abortion. The roots of safed musli are white, smooth and 3-5 inches long. A single plant produces 5-7 tuber roots. The roots of safed musli are used in therapeutic preparations against leucorrhoea. It has been reported that due to its aphrodisiac properties it is used as a tonic for lactating mothers and for women after delivery. Root is also used in commercial preparation of steroidal hormones. Generally, it is used for increasing vitality. Besides this, it is also used in many Ayurvedic preparations prescribed for joint pain, diarrhea, diabetes and also used as a blood purifier. The tubers of safed musli are also used as a substitute for European salad. ${ }^{40}$

The dried safed musli root is well known tonic and aphrodisiac drug given to cure general debility. Roots are generally used in the powder form. Tribal's in the central India use leaves of this herb for vegetables purpose. We found no specific work on any of its chemical ingredients which may be responsible for its medicinal property in the literature reviewed. ${ }^{38}$ Chlorophytum borivilianum Baker (Antharicaceae) commonly referred as 'Safed Musli' has been widely used in the Indian traditional systems of medicine to treat various diseases like rheumatism apart from having immunomodulating property and is used as general tonic. It is also known as 'Ayurvedic viagra' for its aphordisiac properties. C. borivilianum was screened for the first time to determine its antioxidant activity, isolation of the sapogenins and standardization of the isolated sapogenin fraction using HPLC. ${ }^{57}$

Kaushik $^{58}$ reported that the genus Chlorophytum (Liliaceae) owing to the presence of pharmacologically important saponins has attracted interest of the scientific community to investigate the chemistry of the saponins and study their cytotoxicity. Chloromaloside-A having cytotoxicity against cancer cell lines has been isolated from $C$. malayense, while saponins from C. borivilianum are gaining popularity as substitute for viagra. It is a dietary supplement recommended for prenatal and post-natal problems in women. It is known for cure of diabetes, arthritis and gynaecological problems. It also improves the overall immunity of the body. Its consumption is considered an effective means to slow down ageing in humans. ${ }^{50}$

\section{Conclusion}

Medicinal plants have therapeutic potential due to the presence of natural antioxidants functioning as reducing agents, free radical scavengers and quenchers of singlet oxygen. Majority of their antioxidant activity is due to bioactive compounds viz. flavones, isoflavones, flavonoids, anthocyanins, coumarins, lignans, catechins and isocatechins. Currently there has been an increasing interest to identify the antioxidants that are pharmacologically potent with low or no side effects for use in preventive medicine. They have been recognized to possess several medicinal properties (diuretic, expectorant, laxative, anti-bacterial, anti-pyretic etc.) and have been effectively used in the indigenous systems of medicine in India and other countries. Apart from the traditional use, a number of beneficial physiological effects have been identified by extensive studies. Among these are their beneficial effects on lipid metabolism, efficiency as antidiabetics, ability to stimulate digestion and to inhibit platelet aggregation, antioxidant, antilithogenic and anti-inflammatory potential. Demand of herbal food products are increasing day by day in domestic and International markets. Herbal food products are based on edible medicinal plants originated from plants, herbs and aromatic plants. These products may be a good source to fetch foreign money.

\section{Acknowledgments}

None.

\section{Conflict of interest}

Author declares no conflict of interest. 


\section{References}

1. Kumar R, Singh A, Thakur VS. Medicinal and aromatic plants of cold desert areas in Himachal Pradesh. Agrobios Newsletter. 2006;4:53-55.

2. Sen NL. Importance and scope of medicinal and aromatic plants. In: Manua of winter school and commercial exploitation of underutilized MAPs. MPUA\&T, Udaipur; 2004:1-6.

3. Goyal RK, Singh PK, Goyal SK, et al. Uses of Herbal Ingredients in Food Products. In: National Seminar on Recent Advances and Future Challanges in Ayurvdea held on 26th March, 2011 at BHU, RGCS. Barkachha, Mirzapur; 2011 .

4. Nickavar B, Kamalinejad M, Haj-Yahya M, et al. Comparison of the free radical scavenging activity of six Iranian Achillea species. Pharm Biol. 2006;44(3):208-212.

5. Goyal SK, Singh Shree Ram, Singh SP, et al. Antimicrobial and Antioxidan properties of Herbs and Spices. In: Global Scenario of Traditional System of Medicine, Ayurveda, Agriculture and education held on 21-22 Jan. 2013 a BHU, RSGC, Barckachha, Mirzapur; 2013:536-538

6. Dapkevicius A, Venskutonis R, Van Beek TA, et al. Antioxidant activity of extracts obtained by different isolation procedures from some aromatic herbs grown in Lithuania. J Sci Food Agric. 1998;77(1):140-146.

7. Buenz EJ, Schnepple DJ, Bauer BA, et al. Techniques: bioprospecting historical herbal texts by hunting for new leads in old times. Tren Pharmaco Sci. 2004;25(9):494-498.

8. Patwardhan B. AyuGenomics: Integration for customized medicine. Indian J Nat Prod. 2003;19:16-23.

9. Anonymous. Organic farming and medicinal plant cultivation. Agrobios Newsletter. 2005;5-6.

10. Rao MR. New vistas in agroforestry. Agroforestry system, Springer. Netherlands; 2005:107-122.

11. Sharma AK. Medicinal and aromatic plants. Aavishkar Pub. Jaipur (Rajasthan); 2007:62-79.

12. Anonymous. Medicinal and aromatic plants: Need for a strategic approach. The Hindu Survey of Indian Agriculture. 2007;186-192.

13. Anonymous. Medicinal plants-Export market: Advantage India. The Hindu Survey of Indian Agriculture. 2006;208-211.

14. Kurian A. Evaluation and Selection of Medicinal Plants Suitable for a Coconut Based Farming System. Kerala Agri Univ. Vellankkara, Thrissur; 1999.

15. Brahavarchas S. Ayurveda ka pran: Vanaushadhi vigyan (Hindi). Pub. Yug Nirman yojna. Mathura. 2006;83:140-148.

16. Kirtikar KR, Basu BD. Indian Medicinal Plants. Lalit Mohan Basu Allahabad, 1953;3:2033-2044.

17. Aiyer KN, Kolammal M. Pharmacognosy of Ayurvedic Drugs. Journal of Pharmacy and Pharmacology: An International Journal of Pharmaceutical. $1962 ; 65$.

18. Kirtikar KR, Basu BD. Indian Medicinal Plants. Prakash Publishers. Jaipur; 1975:(1-4)

19. Punia MS, Sharma GD, Verma PK, et al. Research on medicinal plants in Haryana, their retrospect and prospects. Proceedings of Regional Seminar on Medicinal plants. Manali, India; 1980:150-154.
20. Shah CS. Recent development of natural products. In: Atal CK, Kapur BM, editors. Cultivation and Utilization of Medicinal Plants. Regional Research Laboratory, Jammu; 1982:24-28.

21. Bhattacharya SK, Ghosal S. Experimental evaluation of the antistress activity of a herbal formulation, Zeestrees. Indian J. Indigenous Medicine. $1993 ; 10(2): 1-8$

22. Shivarajan VV, Balachandran I. Ayurvedic Drugs and their Plant Sources. Oxford and IBH Publishing Co Pvt Ltd. New Delhi; 1994.

23. Chatterjee A, Prakash SC. The Treatise on Indian Medicinal Plants. Publication and Information Directorate, CSIR, New Delhi. 1995;1-4.

24. Warrier PK, Nambiar VPK, Ramankutty C. Indian Medicinal Plants-a compendium of 500 species. Journal of Pharmacy and Pharmacology. $1995 ; 46(11) 1-5$.

25. Jain SK. Medicinal Plants. National Book Trust, New Delhi, India; 1996.

26. Chacko KC. Flowering, fruiting and seed characteristics of Asparagus racemosus. Journal of Economic and Taxonomic Botany. 1997;21(1):113116

27. Shrivastava JL, Pahapalkar MK. Cultivation Trials on Satavar (Asparagus racemosus) in Mandla district of Madhya Pradesh. Vaniki-Sandesh. $1997 ; 21(2): 24-33$

28. CSIR. The Wealth of India-Raw Materials. New Delhi; 1998:1-11.

29. Farooqui AA, Khan MM, Vasundhara M. Productive Technology of Medicinal and Aromatic Crops. Natural Remedies Pvt. Ltd, Bangalore; $1999 \cdot 55-56$

30. Rastogi RP, Mehrotra BN. Compemdium of Indian Medicinal Plants. Central Drug Research Institute, Lucknow and National Institute of Science Communication, New Delhi; 1999:1-3.

31. Singh J, Srivastva RK, Singh AK, et al. Futuristic scenario in production and trade of major medicinal plants in India. J Med Arom Plant Sci. 2000;2223(4A-1A):564-571.

32. Sanghi D, Sharma NJ. Palynological studies of some medicinal plants. $J$. Phytological Res. 2001;14(1):83-90.

33. Singh J, Bangchi GD. Research strategies for development, standardization, quality control and good manufacturing practices (GMPs) for herbal drugs. Proc. First National Interactive Meet on Medicinal and Aromatic Plants, CIMAP, Lucknow; 2002:222-232.

34. Ates DA, Erdogrul OT. Antimicrobial activities of various medicinal and commercial plants extracts. Turkish J Biol. 2003;27(3):157-162.

35. Dubey MK, Kumar R, Tripathi P. Global promotion of herbal medicineIndia's opportunity. Curr Med. 2004;86:37-41.

36. Ravindran PK, Pillai GS, Babu KN. Underutilized herbs and spices. In: KV Peter, editor. Handbook of Herbs and Spices. Woodhead Publishing Ltd, Cambridge; 2004:2.

37. Pandya P, Shambhudas. Old and new herbal remedies. Shri Vedmata Gayatri Trust, Shantikunj, Haridwar (Uttrakhand); 2007:38.

38. Bordia PC, Joshi A, Simlot MM. Safed musli: Advances in horticulture, Medicinal and Aromatic Plants. Malhotra Pub. House, New Delhi. 1995; 11:429-451.

39. Mishra P. Biochemical investigation of Chlorophytum spp. (Safed musli). RAU, Udaipur (Rajasthan); 1994:41. 
40. Rochford H, Grover R. The Rochford book of house plants. Asian Pub. New Delhi; 1961.

41. Sharma PV. Dravyaguna Vigan. Yug Nirman Yojna, Gayatri Tapobhumi, Mathura; 1978:559-566.

42. Mishra B. Bhava Prakash Nighantu (Indian Meterica Medica) commentary by KC Chunekar. 1979;391.

43. Chadha YR, Gupta R, Nagarajan S. Scientific appraisal of some commercially important medicinal plants of India. Indian Drugs and Pharma Indus. 1980;15(2):78.

44. Patel MA, Patel DH, Patel PB, et al. Studies related to domestication and collection of Chlorophytum spp. All India Coordinated Project on Medicina and Aromatic Plants (ICAR). Workshop Report of GAU, Anand (Gujarat); 1991:76-80.

45. Singh D. Udwij Aushadhdravya (Unani Dravyagunadharsh in Hindi) $1974 ; 587$.

46. Chadha KL, Gupta RC. Advances in Horticulture, Medicinal and Aromatic Plants. Malhotra Pub House. New Delhi; 1995:11.

47. Bordia PC. Propagation studies in Safed musli (Chlorophytum spp.). All India Coordinated Project on Medicinal and Aromatic Plants (ICAR), IX Workshop Report. Gujarat Agril. Uni, 1991b;31-42.

48. Singh A, Chauhan HS. Safed musli (Chlorophytum borivilianum) distribution, biodiversity and cultivation. J Med Arom Plant Sci. $2003 ; 25: 712-719$.

49. Kurian A, Sankar MA. Medicinal plants-Horticulture science series-2. New India Pub Agency. New Delhi. 2007;2:4.

50. Singh P, Singh S. Cultivation of safed musli: A medicinal cash crop.
Intensive Agriculture. 2007;45(1):31-33.

51. Seth P, Sharma MK, Simlot MM. Saponin in Chlorophytum spp. In: Paper presented in Diamond Jubilee Annual General Body Meeting of Society of Biological Chemists of India and Biotech. Institute of Chemical Biology, Calcutta; 1991.

52. Newman HAI, Kummerow FA, Scott HA. Dietary Saponin: A factor which may reduce liver and serum cholesterol level. Poultry Sci. 1958;37(1):4246.

53. George AJ. Legal status and toxicity of saponin. Food \& Cosmet Toxicol. $1965 ; 3: 85-91$.

54. Rocher Y. Isolation of saponin from Ficaria ranunculeides. Chem Abst. 1965;64:6418

55. Sambasiva K, Tripathi HC, Jawaharlal, et al. Influence of drugs on male sex behaviour and its pharmacological aspects: A Review. Indian Drugs. 1982;19(4):133-139.

56. Tarafder CR. Ethnogynecology in relation to plants use for abortion. $J$ Econ Taxon Bot. 1983;4(2):507-516.

57. Govindarajan R, Sreevidya N, Vijayakumar M, et al. In-vitro antioxidant activity of ethanolic extract of chlorophytum borivilianum. India J Natur Prod Sci. 2005;11(3):165-169.

58. Kaushik N. Saponins of Chlorophytum spp. J Phytoche (Reviews). 2005;191-196. 